\title{
Segmental hypoplasia of the spinal cord and syringomyelia in a calf
}

\author{
Luciana Aparecida de Souza ${ }^{1}$ (i) Samara de Paula Lopes ${ }^{2}$ Yasmin Daoualibi $^{2}$ \\ Ana Cristina Sbaraini Mósena ${ }^{3}$ Vinícius Vasconcellos da Cruz Gonçalo ${ }^{4}$

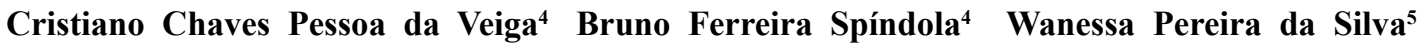 \\ Daniel Guimarães Ubiali² Saulo Andrade Caldas ${ }^{6}$
}

\footnotetext{
${ }^{1}$ Programa de Pós-graduação em Medicina Veterinária, Universidade Federal Rural do Rio de Janeiro (UFRRJ), 23897-000, Seropédica, RJ, Brasil. E-mail: las3souza.vet@gmail.com. *Corresponding author.

${ }^{2}$ Departamento de Epidemiologia e Saúde Pública, Setor de Anatomia Patológica, Universidade Federal Rural do Rio de Janeiro (UFRRJ), Seropédica, RJ, Brasil.

${ }^{3}$ Programa de Pós-graduação em Ciências Veterinárias, Universidade Federal do Rio Grande do Sul (UFRGS), Porto Alegre, RS, Brasil. ${ }^{4}$ Hospital Veterinário, Universidade Federal Rural do Rio de Janeiro (UFRRJ), Seropédica, RJ, Brasil.

${ }^{5}$ Curso de Medicina Veterinária, Fundação Educacional Dom André Arcoverde, Valença, RJ, Brasil.

${ }^{6}$ Departamento de Medicina Veterinária e Cirurgia, Setor de Obstetrícia e Cirurgia Veterinária, Universidade Federal Rural do Rio de Janeiro (UFRRJ), Seropédica, RJ, Brasil.
}

\begin{abstract}
Congenital malformations are functional and structural changes in organ systems, tissues, or organs that may develop during the embryonic or fetal phase. Spinal cord malformations, such as segmental hypoplasia of the spinal cord (SHSC) and syringomyelia, are rare in bovines. A Girolando calf from Valença, Rio de Janeiro, was admitted to the Veterinary Hospital of Universidade Federal Rural do Rio de Janeiro because of motor incoordination. Clinical evaluation revealed a 5 -cm depression area in the spine at the dorsal line of the thoracic region. Neurological examination revealed reduced proprioception, pelvic limb extension with increased nociceptive activity, and reduced anal reflex. In radiographic examination, the body of the T11 vertebra had a trapezoidal wedge shape with ventral hemivertebra, probable agenesis or hypoplasia of the T11-T12 spinous processes, and fusion of the T9-T10 spinous processes. Myelography revealed extradural spinal compression caused by vertebral malformations. Necropsy showed no spinous processes (T11-T12), cranial stenosis in the medullary canal (T11-T13), and 1-3-mm pores in the white matter of the thoracic spinal cord (T8-T11). Microscopy revealed cystic dilatations in the white matter (T9-T11), cystic areas of varying sizes (T8-T9), and moderate reduction in the gray matter around the central canal of the medulla (T11-T13). Here, we reported the clinical and pathological findings of SHSC and syringomyelia in a Girolando calf. The features should be differentiated from other spinal cord syndromes. Congenital malformations are of economic importance, and their etiology and diagnosis are fundamental to disease control and progenitor-selection programs.

Key words: bovine, congenital malformations, myelodysplasia, segmental hypoplasia of the spinal cord, histopathology.
\end{abstract}

Hipoplasia segmentar de medula espinhal e siringomielia em um bezerro

RESUMO: Malformações congênitas são alterações funcionais e estruturais dos sistemas, tecidos ou órgãos que podem ocorrer na fase embrionária ou fetal. Malformações na medula espinhal, como hipoplasia segmentar da medula espinhal (HSME) e siringomielia, possuem raras descrições em bovinos. Uma bezerra Girolando, proveniente do Municipio de Valença, RJ, foi atendida no Hospital Veterinário da Universidade Federal Rural do Rio de Janeiro (UFRRJ), com quadro de incoordenação motora. À avaliação clínica, na coluna vertebral, à linha dorsal da região torácica havia uma área com depressão de $5 \mathrm{~cm}$. Ao exame neurológico foi observado propriocepção reduzida, extensão de membros pélvicos com aumento da atividade nociceptiva e redução de reflexo anal. Ao exame radiográfico, o corpo vertebral T11 apresentou forma trapezoidal em cunha com hemivértebra ventral, provável agenesia ou hipoplasia dos processos espinhosos T11-T12 e fusão dos processos espinhosos T9-T10. À mielografia indicou compressão medular extradural provocada pelas malformações vertebrais. A necropsia não foram observados os processos espinhosos T11-T12, o canal medular apresentou estenose cranial (T11-T13) e, na medula espinhal torácica (T8-T11) foram observados poros de 1-3 mm na substância branca. À microscopia, os segmentos T9-T11 apresentaram dilatações císticas na substância branca e os segmentos T8-T9, formações de áreas císticas de tamanhos variados; nos segmentos T11-T13 denotou-se moderada redução da substância cinzenta ao redor do canal central da medula. O presente trabalho tem o objetivo de apresentar os achados clínicos e patológicos desta bezerra Girolando com HSME e siringomielia, que devem ser diferenciadas de outras síndromes da medula espinhal. As malformações congênitas possuem importância econômica e sua etiologia e diagnóstico são fundamentais para a condução de programas de controle de doenças e seleção de progenitores.

Palavras-chave: bovino, malformações congênitas, mielodisplasia, hipoplasia segmentar da medula espinhal, histopatologia. 
Congenital malformations are functional and structural changes in organ systems, tissues, or organs that may occur in the embryonic or fetal phase (DANTAS et al., 2010; MACEDO et al., 2011). Their etiology in cattle may be associated with infectious agents, ingestion of toxic plants, chemical agents, nutritional deficiencies, and hereditary factors (DE LAHUNTA \& GLASS, 2009; CANTILE \& YOUSSEF, 2016).

Segmental hypoplasia of the spinal cord (SHSC) develops during embryogenesis and is characterized by incomplete formation of one or more segments of the spinal cord, mainly in the thoracolumbar region (CANTILE \& YOUSSEF, 2016). Hypoplasia at T3-L3 causes functional disability of the pelvic limbs (DE LAHUNTA \& GLASS, 2009). It is a rare malformation and is reported particularly in cattle breeds, such as Angus, Hereford, Simmental, Charolais, and Shorthorn (DOIGE et al., 1990). The SHSC has been reported in the Holstein (BINANTI et al., 2012; YILDIRIM et al., 2013), Angus (LEIPOLD et al., 1993), and Japanese Black (IMAI \& MORITOMO, 2009) breeds.

Syringomyelia is the formation of tubular cavitations in the spinal cord not surrounded by the ependyma and separated from the central canal, which distinguishes this medical condition from hydromyelia. Possible causes of the development of congenital syringomyelia are the presence of anomalous vascular pattern and ischemia, which can lead to infarction and a series of events that alter the cerebrospinal fluid (CSF) flow dynamics (CANTILE \& YOUSSEF, 2016).

The diagnoses of SHSC and syringomyelia are based on the clinical and epidemiological histories and findings of imaging, necropsy, and histopathology (BRAUND, 1993). Here in, we reported the clinical and pathological findings of SHSC and syringomyelia in a Girolando calf.

A 15-day-old calf from Valença, Rio de Janeiro, born from a natural mount of a purebred Holstein bull and a multiparous half-blood Girolando cow, was admitted to the Veterinary Hospital of the Universidade Federal Rural do Rio de Janeiro (UFRRJ) because of motor incoordination. The clinical history was obtained from the responsible veterinarian. After the ingestion of colostrum, the calf had been separated from its progenitor, and a depression in the lower back had developed. A few days later, ataxia was observed, and from day 7 , the calf permanently remained in the supine position and underwent artificial milk-feeding. After an infectious etiology was suspected, a blood sample of the progenitor was sent to the Virology Laboratory of the Universidade Federal do Rio Grande do Sul (UFRGS) to search for the bovine viral diarrhea virus (BVDV) RNA through reverse transcription polymerase chain reaction (RT-PCR).

During the clinical evaluation, the calf remained in the supine position and could not stand even with assistance. It had active behavior, body weight of $46 \mathrm{~kg}$, normal-colored ocular and oral mucosae, capillary refill time of $2 \mathrm{~s}$, normal skin turgor, suction reflex, heart rate of 156 beats/ minute, respiratory rate of 88 breaths/minute, and rectal temperature of $39.9{ }^{\circ} \mathrm{C}$. In the spine, there was an area with a $5-\mathrm{cm}$ depression at the dorsal line of the thoracic region (T11 and T12). Neurological examination revealed pelvic limb extension, reduced proprioception, increased nociceptive activity in the pelvic limbs, and reduced anal reflex.

The calf was referred to the UFRRJ Diagnostic Imaging Sector for radiography and myelography. Sedation was performed with propofol $5 \mathrm{mg} / \mathrm{kg}$ for induction and $0.5 \mathrm{mg} / \mathrm{kg} / \mathrm{min}$ for maintenance. Radiography revealed that the body of the T11 vertebra had a trapezoidal wedge shape, probably due to ventral hypoplasia, with ventral hemivertebra. Moreover, there were probable agenesis or hypoplasia of the spinous processes of $\mathrm{T} 11$ and $\mathrm{T} 12$ and fusion of the spinous processes of T9 and T10 (Figure 1A).

For myelography, a non-ionic contrast (Iohexol $300 \mathrm{mg} / \mathrm{mL}$ ) was administered via the brain-medullary cistern at $0.5 \mathrm{~mL} / \mathrm{kg}$. Contrastcolumn narrowing was observed with deviation toward the spinal cord from the T10-T12 caudal region, indicating extradural spinal cord compression caused by vertebral malformations, particularly of T11 (Figures 1B and 1C). Due to the unfavorable prognosis, the calf was euthanized, and necropsy was performed by the team of the Pathological Anatomy Sector of UFRRJ. Fresh fragments from the central nervous system, lungs, thymus, and spleen were collected to search for the BVDV RNA through RT-PCR. The remaining organs were fixed in $10 \%$ buffered formalin and routinely processed for histopathology.

During necropsy, the external examination revealed a dorsal line depression of T11 (Figures $2 \mathrm{~A}$ and $2 \mathrm{C}$ ). In the internal evaluation, the spinous processes of the T11-T12 vertebrae were not observed. The medullary canal showed cranial stenosis at the level of T11-T13 (Figures 2B and 2C). In the T10 and T11 vertebrae, the ventral surface of the medullary body had a concavity headed to the 


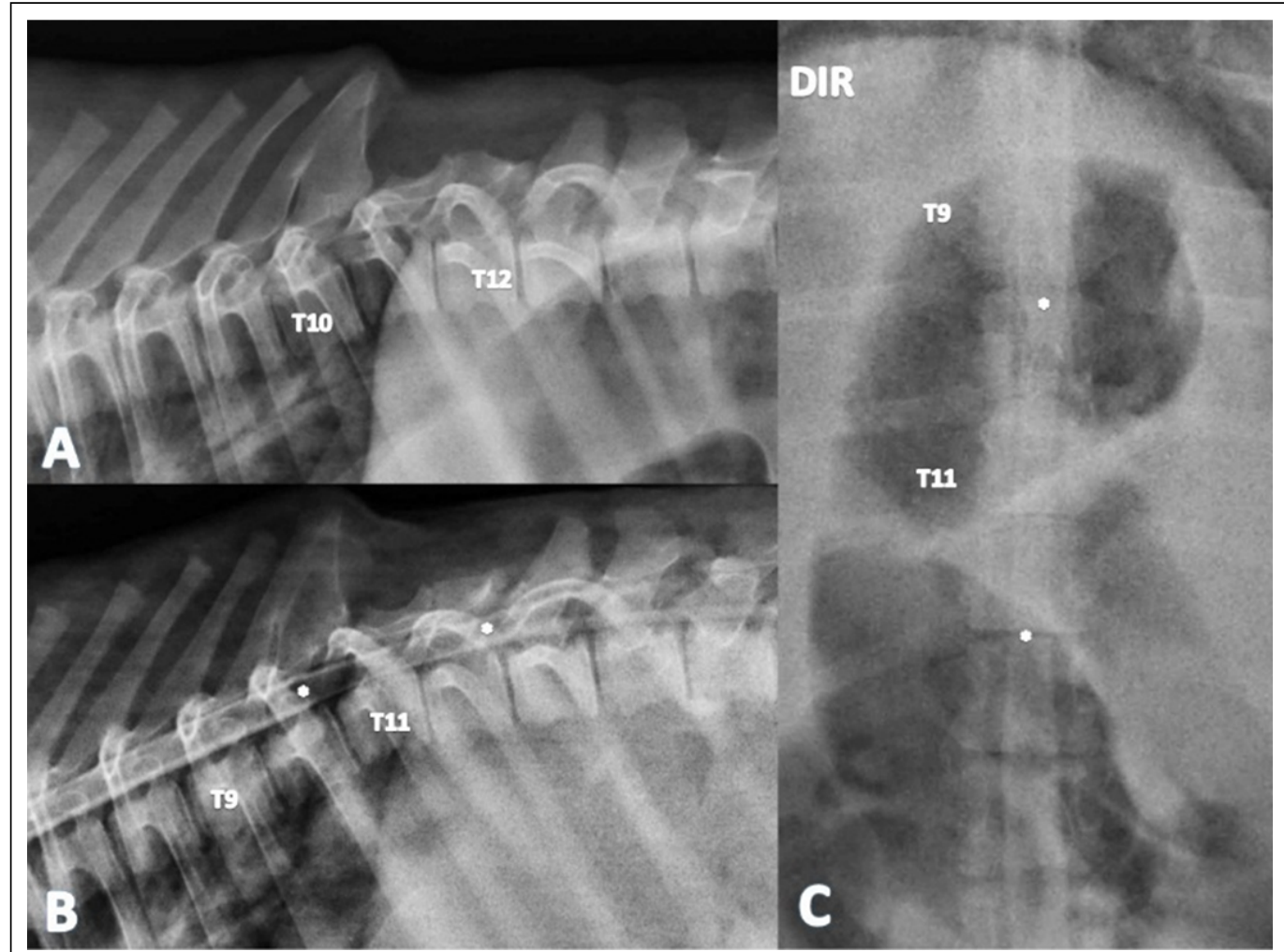

Figure 1 - Regular radiography in the lateral projection in a calf (A) revealing fusion of the spinous processes of T9 and T10. The spinous processes of T11 and T12 are absent. Myelography of the thoracolumbar region of the same calf in the lateral (B) and ventral-dorsal (C) projections reveals contrast-column narrowing with deviation toward the spinal cord (spinal cord region between asterisks) from the caudal region of T10-T12, indicating extradural spinal cord compression caused by vertebral malformations.

dorsal region (Figure 2C). At the cross-section of the thoracic spinal cord (T8-T11), 1-3-mm cystic areas were reported in the white matter, characteristic of syringomyelia, corresponding to the hypoplastic area (Figure 2D).

On microscopy, the T9-T11 segments showed bilateral and ventral cystic dilatations in the white matter (accentuated syringomyelia). The syringomyelia of segments T8 and T9 presented with distinct conformation, characterized by the formation of cystic areas of varying sizes (Figure 2E). In the T9 segment, large cystic areas were observed in the ventral and dorsal spine regions, and small cysts were observed around the vessels, which generated deformation of the medullary gray matter. The T11T13 segments showed a moderate reduction in the gray matter around the central canal of the spinal cord (hypoplasia). In the remaining gray matter of the medullary segments of the atlas, pericariae of neurons with dissolution of the Nissl substance and nuclear pyknosis (chromatolysis) were observed from the T8-T9, T13, and L2-L3 cervical intumescence. The medullary T10 segment and obex presented with central medullary canal ectasia (hydromyelia).

The RT-PCR was performed on samples of the progenitor's blood serum and calf's organs for fragment detection of 119 base pairs of 5'UTR region pestivirus, and the results were negative.

In Brazil, the main causes of congenital malformations in ruminants are the ingestion of toxic plants, such as Mimosa tenuiflora (PIMENTEL et al., 2007; DANTAS et al., 2010) and Poincianella pyramidalis (REIS et al., 2016; MARCELINO et al., 2017), restricted to the Caatinga Biome, in the semiarid region of Northeast Brazil, and absent from the property in the present report. Other infectious agents of congenital malformations and reproductive alterations, such as embryonic death and abortion, 

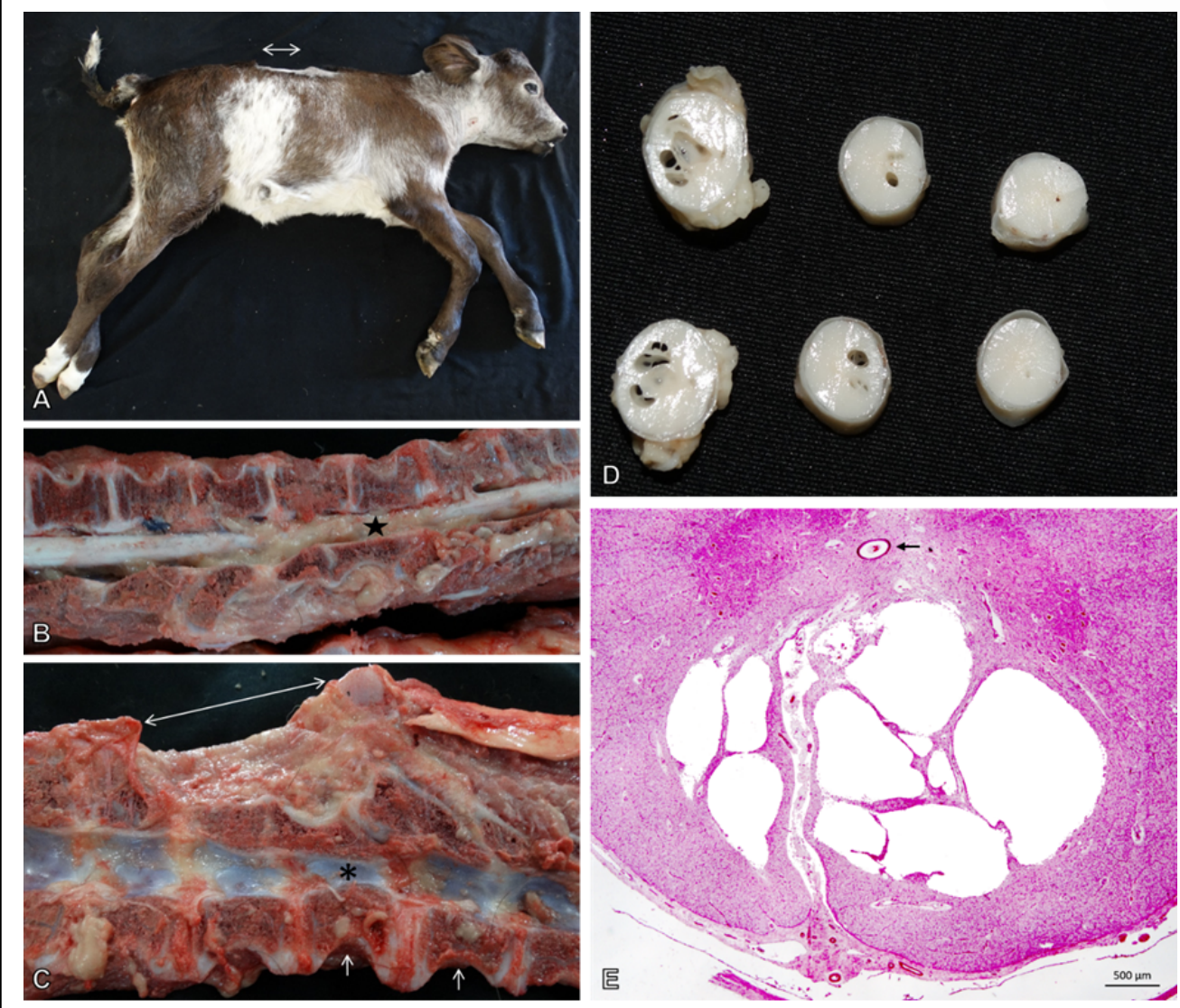

Figure 2 - Segmental hypoplasia of the spinal cord and syringomyelia in a calf. (A) A depression area in the T10 and T11 thoracic regions, indicating the absence of the spinous processes (double arrow). (B) The area of spinal cord hypoplasia with adipose tissue replacing the nerve tissue (star). (C) The medullary canal with reduced diameter (asterisk), absence of the spinous processes (double arrow), and concavities in the ventral surface of the vertebrae (single arrows). (D) Transverse sections of the small-diameter hypoplastic spinal cord and cystic areas. (E) Histological examination of the spinal cord shows cysts replacing the ventral funicular tissue (syringomyelia). The central canal of the medulla is usually covered by the ependyma (arrow). Hematoxylin eosin; Obj. $\times 2.5$.

included the BVDV (PAVARINI et al., 2008; DEZEN et al., 2013) and bluetongue virus (LAGER, 2004; ANTONIASSI et al., 2010).

In the dairy basin from which this calf originated, a molecular diagnosis of BVDV infection had been performed in a cow that aborted a 4-monthold fetus (LOPES et al., 2016). Pestiviruses have teratogenic potential in ruminants (PAVARINI et al., 2008; OTTER et al., 2009; DEZEN et al., 2013). The samples in this report were negative for BVDV in PCR, which does not rule it out as a possible etiological agent of malformations, since BVDV-infected fetuses are immunocompetent after 125 days of gestation, thus eradicating the virus (RIDPATH et al., 2012).
Spinal cord injuries caused by BVDV are relatively rare in bovine fetuses compared to infected sheep fetuses (OTTER et al., 2009). Intrauterine BVDV infection causes mainly cerebellar dysplasia and may be associated with hydranencephaly, hydrocephalus, microcephaly, or porencephaly (VELDHUIS et al., 2013).

Other causes associated with malformations are radiation, cortisones, benzimidazoles, sulfonamides, and organophosphorus compounds. (LEIPOLD \& DENNIS, 1986). In the present report, during the epidemiological evaluation, the clinical history did not lead to the suspicion of teratogenic agents.

As in the present report, YILDIRIM et al. (2013) detected no inflammatory infiltrates in the 
nervous system of a calf with SHSC, suggesting that this lesion may be associated with an anomaly of organogenesis and dependent on a genetic aberration.

Congenital defects are reported worldwide, mainly in the Holstein breed. They can be a typical breed change as the cattle have shared ancestors owing to intensive genetic improvement (AGERHOLM et al., 2001). Thus, the Girolando calf in this report could carry a mutant allele that led to the congenital defect. Similarly, BURGSTALLER et al. (2015) did not rule out the hypothesis of a congenital disorder in a newborn calf with syringomyelia.

Myelodysplastic syndromes, including brachyspine syndrome, Perosomus elumbis infection, and complex vertebral malformation, are reported more frequently than SHSC in calves and should be differentiated from other congenital spinal cord syndromes. The brachyspine differs from SHSC by the presence of a short neck, short trunk, smaller vertebrae, normal limbs, mandibular hypoplasia, and misaligned teeth (TESTONI et al., 2012). Perosomus elumbis is characterized by agenesis or aplasia of the lumbar, sacral, and coccygeal vertebrae, which causes shortening of the animal's body, arthrogryposis of the pelvic limbs, malformation of the musculature, and spinal cord dysplasia (LOPES et al., 2016). In complex vertebral malformations, there are skeletal deformities, deformed vertebrae, hemivertebrae, ankylosis, mainly cervicothoracic, scoliosis, and symmetrical arthrogryposis of the lower limbs (WHITLOCK et al., 2008). Spina bifida is the absence of the dorsal portion of the vertebrae and is usually accompanied by various forms of myelodysplasias (BORGES et al., 1997).

The morphological findings and clinical signs are consistent with SHSC and similar to other cases described in bovines (IMAI \& MORITOMO, 2009; BINANTI et al., 2012; TESTONI et al., 2012; YILDIRIM et al., 2013; BURGSTALLER et al., 2015). In the histopathological analysis of the spinal cord, as seen by ALBERNAZ et al. (2014), depletion of the dorsal and ventral gray horns and reduced white matter structures were observed, confirming SHSC. TESTONI et al. (2012) reported muscle stiffness and atrophy of the pelvic limbs, which differs from the findings reported in this calf. YILDIRIM et al. (2013) reported syringomyelia in a calf with SHSC with no vertebral abnormalities, unlike the calf in the present report. BURGSTALLER et al. (2015) reported syringomyelia in a Simmental calf with clinical and morphological signs similar to the calf in this report.

SHSC is associated with a combination of hydromyelia, syringomyelia, absence or interruption of the central canal, and gray matter dysplasia
(SUMMERS et al., 1995; CANTILE \& YOUSSEF, 2016). In the present report, the calf had hydromyelia, syringomyelia, gray matter hypoplasia (gray horns), and neuronal necrosis. A series of events, such as senility, trauma, infection, or neoplasia, that alter the CSF flow dynamics can lead to fluid accumulation, increased pressure, and spinal cord cavitation called syringomyelia (CANTILE \& YOUSSEF, 2016). Lesions observed on macroscopy and microscopy were sufficient to explain the neurological and medical condition of the spinal cord of this calf. Alterations in the vertebral body and spinous process probably altered the bone dynamics and headed the vertebral body dorsally, which caused spinal cord stenosis and consequent syringomyelia. In humans, SHSC usually causes constriction of the spinal canal and focal vertebral anomalies, and they are associated with spinal dysplasia (YILDIRIM et al., 2013).

SHSC and syringomyelia are rare malformations in calves and should be distinguished from other congenital spinal cord syndromes. Congenital malformations are of economic importance, and their etiology and diagnosis are fundamental for disease control and progenitor-selection programs. For the calf in the present report, radiography and myelography contributed to the diagnosis, indicating bone malformations and spinal cord compression. However, SHSC and syringomyelia could be diagnosed only through necropsy and histopathology.

\section{ACKNOWLEDGEMENTS}

The present study was supported by the Coordination for the Improvement of Higher Education Personnel (Coordenação de Aperfeiçoamento de Pessoal de Nível Superior - CAPES) Brazil (Funding Code 001).

\section{BIOETHICS AND BIOSAFETY COMMITTEE APPROVAL}

We authors of the article entitled "Congenital segmental hypoplasia of spinal cord and syringomyelia in a calf' declared, for all due purposes, the project that gave rise to the present data of the same has not been submitted for evaluation to the Ethics Committee of the "Universidade Federal Rural do Rio de Janeiro", but we are aware of the content of the Brazilian resolutions of the Conselho Nacional de Controle de Experimentação Animal - CONCEA "http://www.mct. gov.br/index.php/content3 10553.html" if it involves animals.

Thus, the authors assume full responsibility for the presented data and are available for possible questions, should they be required by the competent authorities.

\section{DECLARATION OF CONFLICT OF INTERESTS}

The authors declare no conflict of interest. The founding sponsors had no role in the design of the study; in the 
collection, analyses, or interpretation of data; in the writing of the manuscript, or in the decision to publish the results.

\section{AUTHORS' CONTRIBUTIONS}

All authors contributed equally for the conception and writing of the manuscript. All authors critically revised the manuscript and approved of the final version.

\section{REFERENCES}

AGERHOLM, J. S. et. al. Complex vertebral malformation in Holstein calves. Journal of Veterinary Diagnostic Investigation, v.13, n.4., p.283-289, 2001. Available from: <https://www.ncbi. nlm.nih.gov/pubmed/11478598>. Accessed: Jul. 20, 2018. doi: $10.1177 / 104063870101300401$.

ALBERNAZ, V. G. P. et. al. Multiple Segmental Spinal Cord Hypoplasia in a Cat. Acta Scientiae Veterinariae, v.42, p.16, 2014. Available from: <https://www.researchgate.net/ publication/281715337_Hipoplasia_medular_segmentar multipla_em_um_felino_domestico_Multiple_Segmental_Spinal_ Cord_Hypoplasia_in_a_Cat>. Accessed: Jul. 20, 2018.

ANTONIASSI, N. A. B. et. al. Clinical and pathological changes in sheep naturally infected with bluetongue virus in Rio Grande do Sul, Brazil. Pesquisa Veterinária Brasileira, v.30, p.1010-1016, 2010. Available from: <http://www.scielo. br/scielo.php?pid=S0100-736X2010001200002\&script $=$ sci abstract $>$. Accessed: Sep. 9, 2018. doi: 10.1590/s0100$736 \times 2010001200002$.

BINANTI, D. et. al. Segmental spinal cord hypoplasia in a Holstein Friesian calf. Anatomia, Histologia, Embryologia, v.42, p.316-320, 2012. Available from: <https:/www.researchgate.net/ publication/232698059_Segmental_Spinal_Cord_Hypoplasia_ in_a_Holstein_Friesian_Calf $>$. Accessed: Jul. 20, 2018. doi: $10.1 \overline{1} 11$ /ahe. $1 \overline{2} 012$

BORGES, A. S. et. al. Myelodysplasia and spina bifida in ruminants: A case report. Arquivo Brasileiro de Medicina Veterinária e Zootecnia, v.49, p.685-692, 1997. Available from: $<$ https://repositorio.unesp.br/handle/11449/65237>. Accessed: Sep. 10, 2018.

BRAUND, K. G. Clinical Syndromes in Veterinary Neurology. $2^{\text {nd }}$ edn. St. Louis : Mosby, 1993, 477p.

BURGSTAlleR, J. et al. Syringomyelia in a Newborn Male Simmental Calf. Journal of Veterinary Internal Medicine, v.29, n.6, p.1633-1637, 2015. Available from: <https:/www.ncbi.nlm. nih.gov/pmc/articles/PMC4895670/>. Accessed: Jul. 20, 2018. doi: $10.1111 /$ jvim. 13646 .

CANTILE, C.; YOUSSEF, S. Nervous sistem. In: MAXIE, M.G. (Ed) Jubb Kennedy and Palmer's Pathology of Domestic Animals. $6^{\text {th }}$ edn. Guelph : Elsevier, 2016. p.251-406. v.1.

DANTAS, A. F. M. et. al. Congenital malformations in ruminants in the semiarid of the Brazilian Northeast. Pesquisa Veterinária Brasileira, v.30, p.807-815, 2010. Available from: <https:// www.researchgate.net/publication/228651289_Malformacoes congenitas em ruminantes_no semiarido do_Nordeste Brasileiro>. Accessed: Jul. 24, 2018. doi: 10.1590/S0100736X2010001000002.
DE LAHUNTA, A.; GLASS, E. Development of the nervous system: malformation. In: DE LAHUNTA, A.; GLASS, E. (Eds), Veterinary Neuroanatomy and Clinical Neurology. $3^{\text {rd }}$ edn. St. Louis: Saunders Elsevier, 2009. p.23-53.

DEZEN, S. et. al. Bovine viral diarrhea virus (BVDV) infection profile in a high production dairy herd with vaccination program against BVDV. Pesquisa Veterinária Brasileira, v.33, n.2, p.141-147, 2013. Available from: <http://www.scielo.br/scielo. php? script $=$ sci_arttext\&pid $=$ S0100-736X2013000200002>. Accessed: Sep. 10, 2018. doi: 10.1590/s0100-736x2013000200002.

DOIGE, C. E. et al. Congenital spinal stenosis in beef calves in western Canada. Veterinary Pathology, v.27, n.1, p.16-25, 1990. Available from: <https://journals.sagepub.com/doi/10.1177/030098589002700 103>. Accessed: Jul. 24, 2018. doi: 10.1177/030098589002700103.

IMAI, S.; MORITOMO, Y. Segmental hypoplasia of the spinal cord in a Japanese Black calf. Journal of Veterinary Medical Science, v.71, p.337-340, 2009. Available from: <https://www. ncbi.nlm.nih.gov/pubmed/19346703>. Accessed: Jul. 20, 2018. doi: $10.1292 /$ jvms.71.337.

LAGER, I. A. Bluetongue virus in South America overview of viruses, vectors, surveillance and unique features. Veterinaria Italiana, v.40, p.89-93, 2004. Available from: <https://www.ncbi. nlm.nih.gov/pubmed/20419641>. Accessed: Sep. 10, 2018.

LEIPOLD, H. W.; DENNIS, S.M. Congenital defects affecting bovine reproduction. In: MORROW, D.A. (Ed.) Current therapy in theriogenology: diagnosis, treatment and prevention of reproductive diseases in small and large animals. Philadelphia: W.B. Saunders Company, 1986. p.177-199.

LEIPOLD, H. W. et. al. Congenital defects of the bovine central nervous system. Veterinary Clinics of North America: Food Animal Practice, v.9, n.1, p.77-91, 1993. Available from: $<$ https:// www.sciencedirect.com/science/article/pii/S0749072015306733>. Accessed: Jul. 24, 2018. doi: 10.1016/s0749-0720(15)31188-9.

LOPES, S. P. et. al. Perosomus elumbis em bovino Girolando: Relato de caso. Pesquisa Veterinária Brasileira, v.36, p.156159, 2016. Available from: <https:/www.researchgate.net/ publication/320215557_Perosomus_elumbis_em_bovino_ Girolando_relato_de_caso $>$. Accessed: Sepp. 10, 2018.

MACEDO, J. T. S. A. et. al. Congenital defects in cattle from central Rio Grande do Sul, Brazil. Pesquisa Veterinária Brasileira, v.31, p.297-306, 2011. Available from: <http://www.scielo.br/scielo. php?pid=S0100-736X2011000400005\&script $=$ sci_abstract\&tlng $>$. Accessed: Jul. 20, 2018. doi: 10.1590/s0100-736x2011000400005.

MARCELINO, S. A. C. et. al. Malformations in small ruminants in the semi-arid region of Bahia: epidemiological, clinicalpathological and radiological aspects. Pesquisa Veterinária Brasileira, v.37, p.1437-1442, 2017. Available from: <http:// www.scielo.br/scielo.php?script $=$ sci_abstract\&pid=S0100-736X2 $017001201437 \& \operatorname{lng}=$ pt\&nrm $=$ iso $>$. Accessed: Jul. 20, 2018. doi: $10.1590 / \mathrm{s} 0100-736 \times 2017001200013$.

OTTER, A. et. al. Congenital tremor and hypomyelination associated with bovine viral diarrhoea virus in 23 British cattle herds. Veterinary Record, v.164, n.25, p.771-778, 2009. Available from: $<$ https://www.researchgate. net/publication/26307289 Congenital tremor and hypomyelination associated_with_bovine_viral_diarrhoea_virus_in_23_British_cattle_ herds $>$. Accessed: Sep. $10,201 \overline{8}$. doi: $10.1136 /$ vr. $164.25 . \overline{7} 71$. 
PAVARINI, S. P. et. al. Congenital anomalies in aborted bovine fetuses in Southern Brazil. Pesquisa Veterinária Brasileira, v.28, p.149-154, 2008. Available from: <http://www.scielo.br/scielo. php?script=sci_abstract\&pid=S0100-736X2008000300004\&lng= en\&nrm=iso\&tlng=pt $>$. Accessed: Jul. 24, 2018.

PIMENTEL, L. A. et. al. Mimosa tenuiflora as a cause of malformations in ruminants in the northeastern Brazilian semiarid rangelands. Veterinary pathology, v.44, n.6, p.928-931, 2007. Available from: <https://journals.sagepub.com/doi/10.1354/vp.446-928>. Accessed: Aug. 6, 2018. doi: 10.1354/vp.44-6-928.

REIS, S.D.S. et. al. Congenital malformations and other reproductive losses in goats due to poisoning by Poincianella pyramidalis (Tul.) L.P. Queiroz (Caesalpinia pyramidalis Tul.). Toxicon, v.118, p.91-94, 2016. Available from: <https://www.sciencedirect.com/ science/article/pii/S0041010116301167?via\%3Dihub>. Accessed: Aug. 6, 2018. doi: 10.1016/j.toxicon.2016.04.043.

RIDPATH, J. F. et. al. Flaviviridae. In: FLORES, E.F. (Ed.). Virologia Veterinária - Virologia geral e doenças víricas. $2^{\text {nd }}$ edn. Ed. Santa Maria : Editora UFSM, 2012. p.657-690.

SUMMERS, B. A. et. al. Veterinary Neuropathology. St. Louis : Mosby, 1995, 527p.
TESTONI, S. et. al. Ultrasonographic diagnosis of syringohydromyelia and segmental hypoplasia of the lumbar spinal cord in a calf. Journal of Veterinary Internal Medicine, v.26, p.1485-1489, 2012. Available from: <https://onlinelibrary.wiley. com/doi/full/10.1111/j.1939-1676.2012.00989.x>. Accessed: Aug. 6, 2018. doi: 10.1111/j.1939-1676.2012.00989.x.

VELDHUIS, A. M. et. al. Schmallenberg virus epidemic in the Netherlands: spatiotemporal introduction in 2011 and seroprevalence in ruminants. Preventive Veterinary Medicine, v.112, p.35-47, 2013. Available from: $<$ https://www.sciencedirect. com/science/article/pii/S0167587713002092?via\%3Dihub $>$. Accessed: Sep. 13, 2018. doi: 10.1016/j.prevetmed.2013.06.010.

WHITLOCK, B. K. et. al. Heritable bovine fetal abnormalities. Theriogenology, v.70, n.3, p.535-549, 2008. Available from: $<$ https://www.ncbi.nlm.nih.gov/pubmed/18514810>. Accessed: Aug. 6, 2018. doi: 10.1016/j.theriogenology.2008.04.016.

YILDIRIM, F. et. al. Congenital segmental hypoplasia of the spinal cord in a Holstein calf. Kafkas Üniversitesi Veteriner Fakültesi Dergisi, v.19, p.1049-1052, 2013. Available from: <https://www. researchgate.net/publication/269405232_Congenital_Segmental_ Hypoplasia_of the_Spinal_Cord_in_A_Holstein_Calf $>$. Accessed: Aug. 6, 2018. doi: 10.9775/kvfd.2013.9166. 